2. Степанов Ю.С. Константы: Словарь русской культуры, изд. 3-е, испр. и доп.. М., Академический проект, 2004, 992 с.

3. Фасмер Макс Этимологический словарь русского языка. В 4 т. Т.3 (Муз-Сят). Пер. с нем. и доп. О.Н.Трубачева, 2-е изд, стер., М., Прогресс, 1987, $832 \mathrm{c}$.

4. Truth. https://en.wikipedia.org/wiki/Truth\#: :text=Definition\%20and $\% 20$ etymology,Further\%20information $\% 3 \mathrm{~A} \% 20$ Veritas\&text=The $\% 20$ Englis $\mathrm{h} \% 20$ word $\% 20$ truth $\% 20$ is, German $\% 20$ triuwida $\% 2 \mathrm{C} \% 20 \mathrm{Old} \% 20$ Norse $\% 20 \mathrm{tr}$ ygg\%C3\%B0.\&text=Old $\% 20$ Norse $\% 20$ tr $\% \mathrm{C} 3 \% \mathrm{BA} \% 2 \mathrm{C} \% 20 \% 22$ faith $\% 2 \mathrm{C}$,f aith\%22\%2C\%20compare\%20\%C3\%81satr\%C3\%BA)) (дата обращения: 3.04.2021).

DOI https://doi.org/10.30525/978-9934-26-073-5-2-61

\title{
ЩОДО МОДЕЛЮВАННЯ ЛЕКСИЧНОГО ЗНАЧЕННЯ ДИХОТОМІЇ «СВІЙ / ЧУЖИЙ» З УРАХУВАННЯМ НАЯВНОСТІ ФРАЗЕОЛОГІЗМУ
}

\author{
Шепель Ю. О. \\ доктор філологічних наук, професор, \\ професор кафедри перекладу \\ та лінгвістичної підготовки іноземчів, \\ академік Національної академії наук вищої освіти України, \\ Дніпровського начіонального університету імені Олеся Гончара
}

\section{Панченко О. I.}

доктор філологічних наук, професор, професор кафедри перекладу та лінгвістичної підготовки іноземців, Дніпровського начіонального університету імені Олеся Гончара м. Дніпро, Україна

Під час аналізу значення фразеологізмів важливим $є$ виокремлення сем, семантичних елементів менших, ніж той або той аспект фразеологічного значення.

Чеський лінгвіст В. Скаличка запропонував термін «сема» для позначення мікроелемента плану змісту. Семи - свого роду «атоми» значення, що входять до складу макроелементів - аспектів значення. Семи можна схарактеризувати як мікроелементи значення, що позначають реальні або уявні ознаки денотатів. В. Г. Гак визначає три типи 
сем: архисеми (загальні семи родового значення), диференційні семи видового значення та потенційні семи, які відображають другорядні характеристики позначуваного об'єкта [1, с. 371].

1. За характером виявлення у значенні виокремлюють експліцитні та імпліцитні семи.

Експліцитні семи - це інформація, що безпосередньо представлена у значенні. Вони можуть бути точними та образними. Під імпліцитними семами розуміють ті елементи значення, які присутні в плані змісту, але відсутні в плані вираження. Імпліцитні семи передають обсяг імпліцитної інформації у структурі значення. Імпліцитність у сфері фразеології пов'язана з лаконізацією значення, з асиметрією плану змісту і плану виразу. Семи «свого» $i$ «чужсого» спостерігаємо, наприклад, у прислів'ї «Every man is the architect of his own fotrune». Ця фразеологічна одиниця має значення «еverybody is able to achieve his / her aims that bring happiness and satisfaction, but to achieve this, it's quite important to make every effort». Це значення $\epsilon$ сигніфікатом фразеологічної одиниці, денотативний аспект - усі висловлювання, вчинки, які необхідно виконати людині, а також старання та зусилля, яких докладає людина, щоб досягти успіхів у житті, конотативний аспект - експресивність, створювана образністю. Архисема - «факт того, що у людини $\epsilon$ цілі й завдання на життя». Диференційна сема - «цілеспрямованість, самовпевненість» і т. ін., тобто те, чим володіє людина, щоб досягти свого щастя. Такі семи можуть виокремлюватися не лише у прислів'ях, але й в фразеологічних одиницях інших структурних типів, скажімо, у фразеологізмах: «lift oneself by one's own bootlaces» - «виходити в люди завдяки власним зусиллям», "pick smb's brains» - «використовувати чужі думки», «еat smb's bread» - «їсти чужий хліб», «a cock in valiant on his own dunghill» - «на своїи купі гною і півень сміливець», «kеер опе's counsel» - «не висловлювати своїх поглядів».

Інформація в експліцитних семах безпосередньо представлена у значенні. Вони можуть бути конкретними або образними, пор.: пряму сему «їсти чужий хліб, жити за чужий рахунок» виокремлюємо в прислів"i «eat smb's bread». Прикладом виявлення подібної семи може слугувати фразеологічна одиниця «East or west home is best»-y гостяx добре, а вдома краще. У цьому прислів'ї спостерігаємо порівняння свого й чужого - вдома (своє) і нерідного місця (чуже). Імпліцитні семи представлені в таких фразеологічних одиницях, як: Beam in one's eye «колоду в своєму оиі», No garden without its weeds - «Немає троянди без шипів». 
2. Класифікація сем за змістом передбачає визначення чітких i нечітких сем.

«Чіткі семи - це семи, зміст яких позбавлений суб’єктивізму.

Нечітка сема має розмитий, нечітко окреслений зміст. Такі нечіткі семи становлять собою поняття, що мають об'єктивний, загальний для всіх зміст, але суб'єктивний обсяг» [2, с. 67]. Наприклад, чіткою архисемою у фразеологізмі «cut from the same cloth»є негативна оцінка чоловіка і жінки. Денотат, позначений цією фразеологічною одиницею, визначаємо як «two persons of the same character». Нечіткість сигніфіката «people of the same character», "persons who worth of each other» призводить до розмитості обсягу поняття, що складається 3 нечітких сем негативної оцінки: «два чобота пара», «одного поля ягоди», «варті один одного».

3. За змістом визначають також позитивні і негативні семи.

Позитивні семи відображають ознаки, що наявні у денотатах, а негативні - значущу відсутність у денотаті певної ознаки. Наведені нижче приклади ілюструють ці типи сем. Наприклад, у фразеологізмі «batting average» позитивною семою $\epsilon$ «success», «achievement».

Також зазначу, що негативна сема виражена майже завжди експліцитно у всіх фразеологічних одиницях, до складу яких входять негативні частки no i not, наприклад: «two blacks do not make a white»«чужим гріхом свого не спокутуєш». Негативна сема - «do not make a white». Характерною особливістю семантики таких зворотів є не тільки експліцитне вираження негативної семи, але й наявність позитивної семи, імпліцитно вираженої. Це можна пояснити тим, що будь-яке заперечення містить твердження, яке може бути підтверджене дефініціями негативних зворотів, як-от: «there is no joy without alloy»«немає троянди без шипів», though everything has its own defects and imperfection, it is only by endurance, effort, that perfection and beauty is to be attained.

4. У семантичній структурі фразеологізму можуть бути виокремлені граматичні семи - макро- та мікроелементи граматичного значення. До макроелементів відносять категорійні семи найбільш узагальненого граматичного значення, наприклад, семи, що позначають дію, предметність, стан. До мікроелементів уналежнюють, наприклад, семи, що позначають число, рід та відмінок, дійсний i пасивний стани. Наприклад, семи позначають дію: «carry the baby» - «няня чужсӧ дитини, відповідати за будь-кого», «соте between the bark and the tree»»втручатися у чужі сімейні справи», "dо опе's bit» - "робити свій внесок», стан: «be off one's own beat»- «бути не в собi», «be in smb's 
boots» - «бути на бути на одній нозі з кимось; таким, як хтось», «like a cat on hot bricks» - «не по собi».

Водночас існують семи однини, які характерні для субстантивних фразеологічних одиниць, що позначають одиничні денотати: «a chip of the old block» - «син свого батька». Семи множини спостерігаємо у фразеологічних одиницях, що позначають два денотати або більше: «nо garden without its weeds» - Усе має свої недоліки, немає нічого досконалого.

Концепт «свій - чужий» $є$ амбівалентним, оскільки характеризує різні грані та градацію міжкультурних взаємовідношень, водночас поєднуючи уявлення про «культурне» та «іншокультурне», які, самі по собі, досить умовні й варіативні - залежно від культурно-історичного та побутового контексту, від характеру і стилю міжкультурної комунікації і т. ін. Так, зокрема, концепт «свій - чужий» передбачає, по-перше, осмислення культурно-»свого» на тлі «чужого» і одночасно культурно-»џужсого» на тлі «свого». По-друге, у процесі міжкультурної комунікації «чужого» надається характер доступного, «особистого», при цьому, тією чи тією мірою, досягається відносне наближення, розуміння і засвоєння «чужого», тобто переведення культурних артефактів 3 простору «чужого» до простору «свого».

Отак, проведене дослідження показало, що концептуальна опозиція «свій - чужсий» реалізується через мовні засоби, а саме через метафору. При цьому концептуальна опозиція «свій - чужий» інтегрує вербальні засоби різних рівнів для створення оцінки, яка зорієнтована на ефективність впливу на суспільну свідомість 3 метою інтервенції влади й яка випливає із співвіднесення об'єкта 3 зоною «свого» або 3 зоною «чужого».

\section{Література:}

1. Гак В.Г. К проблеме семантической синтагматики. Проблемь структурной лингвистики 1971: Сб. Москва: Наука, 1972. С. 367-395.

2. Стернин И.А. Лексическое значение слова в речи. Воронеж: Издво Воронежского ун-та, 1985. 112 с. 